\title{
Addressing Alcohol in the Context of Elementary Education: the Social Imaginary Reconstruction of Teachers
}

\author{
Ingryd Cunha Ventura Felipe ${ }^{1}$
}

Antonio Marcos Tosoli Gomes ${ }^{2}$

\begin{abstract}
Alcohol consumption is considered a global problem, principally affecting adolescents. In this context, the aims of this study were to identify the pedagogical strategies developed by elementary school teachers in the approach to alcohol with adolescents; To analyze the attitudes, beliefs, values and practices of the elementary school teachers in relation to alcohol; To discuss the repercussions of the attitudes, beliefs, values and practices of the teachers about alcohol in the dialogue with the students and in the implementation of the strategies referred to above. This was a qualitative study performed with 26 teachers of a Rio de Janeiro public school. The data were analyzed through thematic content analysis and grouped into 5 categories. It was concluded that social imaginary and attitudinal construction of the teachers directly interferes with the personal and professional practice and has repercussions in the quotidian life of the students. It was noted that the focus should not just be on the students, but on the relationship of the teachers with their pedagogic strategies.
\end{abstract}

Descriptors: Alcohol Drinking; Health Education; Primary Prevention; School Health.

\footnotetext{
${ }^{1}$ RN, M.Sc. in Nursing. E-mail: ingrydventura@hotmail.com.

2 RN, Ph.D. in Nursing, Adjunct Professor, Faculdade de Enfermagem, Universidade do Estado do Rio de Janeiro, RJ, Brazil. E-mail: mtosoli@gmail.com.
}

Corresponding Author:

Ingryd Cunha Ventura Felipe

Universidade Estadual do Rio de Janeiro. Faculdade de Enfermagem.

Boulevard 28 de Setembro, 157, 70 andar

Vila Isabel

CEP: 20551-030 Rio de Janeiro, RJ, Brasil

E-mail: ingrydventura@hotmail.com 


\title{
A abordagem do álcool no contexto do ensino fundamental: a reconstrução socioimaginária dos docentes
}

O consumo de álcool é considerado problema mundial, afetando principalmente os adolescentes. Nesse contexto, adotaram-se como objetivos identificar as estratégias pedagógicas desenvolvidas pelos professores do ensino fundamental, na abordagem sobre o álcool junto aos adolescentes, analisar as atitudes, crenças, valores e práticas dos professores do ensino fundamental em relação ao álcool, discutir as repercussões das atitudes, crenças, valores e práticas dos professores sobre álcool, na interlocução com os alunos e na implementação das estratégias suprarreferidas. Trata-se de estudo qualitativo, realizado com 26 professores de uma escola municipal do Rio de Janeiro. Os dados foram tratados por meio da análise de conteúdo temática e agrupados em 5 categorias. Conclui-se que a construção socioimaginária e atitudinal dos docentes interferem diretamente na prática pessoal e profissional, repercutindo no cotidiano dos alunos. Destaca-se que o foco não deve ser apenas os estudantes, mas a relação dos professores com suas estratégias pedagógicas.

Descritores: Consumo de Bebidas Alcoólicas; Educação em Saúde; Prevenção Primária; Saúde Escolar.

\section{El abordaje del alcohol en el contexto de la enseñanza fundamental: la reconstrucción socio imaginaria de los docentes}

\begin{abstract}
El consumo de alcohol es considerado un problema mundial, afectando principalmente a los adolescentes. En este contexto, se adoptaron como objetivos: identificar las estrategias pedagógicas desarrolladas por los profesores de la enseñanza fundamental en el abordaje sobre el alcohol junto a los adolescentes; analizar las actitudes, creencias, valores y prácticas de los profesores de la enseñanza fundamental en relación al alcohol; y, discutir las repercusiones de las actitudes, creencias, valores y prácticas de los profesores sobre alcohol en la interlocución con los alumnos y en la implementación de las estrategias seleccionadas. Se trata de estudio cualitativo realizado con 26 profesores de una escuela municipal de Rio de Janeiro. Los datos fueron tratados a través del análisis de contenido temático y agrupados en 5 categorías. Se concluye que la construcción socio-imaginaria y la actitud de los docentes interfieren directamente en la práctica personal y profesional repercutiendo en lo cotidiano de los alumnos. Se destaca que el enfoque no deben ser apenas los estudiantes, se debe también considerar la relación de los profesores con sus estrategias pedagógicas.
\end{abstract}

Descriptores: Consumo de Bebidas Alcohólicas; Educación en Salud; Prevención Primaria; Salud Escolar.

\section{Introduction}

Alcohol use has been historically institutionalized. Initially, alcohol brings a sense of pleasure and satisfaction, i.e. a brief euphoria that is approved of by society. However, its continued use or dependence brings more serious consequences such as depression, excessive spending, family disturbances and difficulty in social and employment relationships, directly affecting the lives of those who abuse this substance and this dependency is condemned by society. Alcohol consumption is considered a public health problem worldwide and has affected mainly adolescents. A thematic approach to the phenomenon of drugs in schools helps in the interactive process between teachers, students, principals, families and community in a dynamic where "everyone is 
mobilized for the integral development of individuals, with a view that education begins in school and continues in the life in society"(1).

A study conducted with teachers and students pointed out that the school does not provide a healthy environment, that drug use occurs within institutions and that prevention programs do not reach all of the students $^{(2)}$. Another study conducted in Florianopolis, in turn, found that elementary school teachers have a dualistic and simplified view about drug use by adolescents, imposing guilt for using on the person. The authors state that "preventive practices must develop, in classrooms, discussion of its peculiarities, of its reality, creating their own ways to approach it. However, it is indicative of the need to develop the skills of the elementary school teachers in addressing the issues of use/abuse of drugs and reinforces the important role of the school in prevention"(3).

To achieve the complexity of this subject, some aims were identified: 1) To identify the pedagogical strategies developed by elementary school teachers in the approach to alcohol with adolescents; 2) To analyze the attitudes, beliefs, values and practices of the elementary school teachers in relation to alcohol; 3) To discuss the repercussions of the attitudes, beliefs, values and practices of teachers about alcohol in the dialogue with the students and in the implementation of the strategies referred to above.

The national and international policies emphasize the importance of reducing the consumption of drugs, with it being necessary to fully address all the issues involved and not just the substance. The control of the use/abuse of drugs has become a major issue in global agendas due to the damage to the social, economic and political aspects of the country. Multicenter studies have shown that the current context requires skilled professionals capable of creating solutions or strategies to problems based on scientific data, emphasizing the academic programs of professional training in the various areas of knowledge $\mathrm{e}^{(2-4)}$.

\section{Theoretical framework}

The theoretical framework of this study is based on the intersection of the concepts of beliefs, attitudes and values ${ }^{(5)}$ with the concepts promoted by social psychology, especially in regard to behavior and social interaction, i.e. in the relationship between subjects and reality ${ }^{(6)}$. From this intersection of the theoretical framework, beliefs are considered as inferences made by the observer about states of basic expectations. The beliefs function predisposed to induce an attitude in response to an object, fact or situation ${ }^{(5)}$.

From this, the attitude can be understood as "a relatively enduring organization of beliefs around an object or situation predisposing one to respond in some preferential manner"(5). The way a person behaves faced with a situation or object will depend, on one hand, on the particular beliefs and predispositions activated by the object of attitude and, on the other hand, by the beliefs or predispositions activated by the situation(5). However, values "are abstract ideals, positive or negative, not tied to any specific attitude object or situation, representing a person's belief about ideal modes of conduct and ideal terminal goals"(5). Social standards are learned during the gathering in groups and are an important mechanism of social control of individual behavior. The social role addresses the identity in a situational perspective, while at the same time the notion of self results in the recognition of standards and values associated with the positions occupied at a given time and this knowledge corresponds to a form of adaptation of individual action to the context ${ }^{(7)}$.

Social behavior is determined by the interaction between the attitude and the situation, i.e. "it is a function of the interaction between two attitudes attitude toward the object and attitude towards the situation"(5). Social interaction concerns the reality of quotidian life that is shared with others, i.e. in the face to face situation the other becomes perceived by me in a present experienced by the subjects, at the same time that I am perceived by the other. In this situation, the other is plainly real and this solidity makes up part of the global reality of quotidian life(6).

To contextualize these theoretical concepts, some relevant data is presented on alcohol consumption and its approach in schools, the focus of this study, for better visualization of the interactions that were investigated. The harmful use of alcohol is responsible for about 3\% of all deaths that occur on the planet, ranging from liver cancer and cirrhosis to accidents, falls, poisoning and murder. In developing countries, including Brazil, alcoholic beverages are a major factor in disease and mortality, with their deleterious impact being considered as between $8 \%$ and $14.9 \%$ of all health problems of these nations ${ }^{(8)}$. A study performed in 27 Brazilian State capitals among students in elementary and high school education of the public network, conducted in 2004, identified that $65.2 \%$ of students had used alcohol during their lives, showing that $41.2 \%$ were in the age group 10-12 years $^{(9)}$. 
In this perspective, the school constitutes an important space for discussions and interactions, where young people spend most of their time, presenting a key role in the discipline and education of children and adolescents and contributing to the construction of their principles of life. It is noteworthy that in the context of the drug phenomenon in schools, it is understood that information is not sufficient to promote the health of students $^{(7-10)}$. At the same time, it is comprehended that the parameters of guidance on preventing the use/abuse of drugs recognize, as the most effective interventions, "the continuous education actions, which offer possibilities for elaboration of the information received and discussion of the emotional and cultural obstacles that impede the adoption of preventive measures"(10).

\section{Methodological approach}

This was a descriptive study with a qualitative approach considering the subjectivity that the issue presents. In this context, qualitative research is defined as an approach that addresses very specific issues and works "with the universe of meanings, motives, aspirations, beliefs, values and attitudes", and also addresses a reality that cannot be quantified(11).

The study was conducted in a public, municipal school in Rio de Janeiro, covering elementary students from the $6^{\text {th }}$ to $9^{\text {th }}$ grade. The study subjects were 26 school teachers responsible for the classes, allocated in this municipal teaching institution who voluntarily agreed to participate in the study and who give classes in the morning and afternoon shifts. It is noteworthy that the group of subjects interviewed covered all disciplines offered in the school and planned by the Ministry of Education. All of the teachers belonging to the morning and afternoon shift were invited to participate in the study, two from the morning shift and one from the afternoon shift withdrew their participation on the day of the interview, which was respected as a principle of the research ethics.

To achieve the subjectivity of the proposed objectives together with the subjects, the semi-structured interview was used, consisting of a script containing 12 questions that address the following themes: knowledge about alcohol and teaching strategies; professional practices adopted in classrooms; and personal, professional and familial experiences with the use/abuse of alcohol. The interviews, recorded on a Media Player 3 device with a mean duration of 22 minutes, nine hours and 25 minutes in total, were performed in the school between the months of January and February 2009, and later transcribed into a text editor to facilitate the use of printed material.

Regarding the ethical issues it is pertinent to emphasize that the project was approved by the Research Ethics Committee of the State University of Rio de Janeiro (COEP/UERJ Protocol n 024.3.2008) and authorized by the Municipal Department of Education of Rio de Janeiro and by the school institution where data were collected. Rights of the participants were met by reading and signing of the free prior informed consent form before starting the interviews.

The data were processed through thematic content analysis, which is defined as "a set of techniques of communication analysis that aim, through systematic and objective procedures to describe the content of the messages, to obtain indicators, quantitative or not, that permit the inference of knowledge related to the conditions of the production/reception of these messages"(12).

\section{Analysis and Discussion of the Results}

Analysis of the interviews took place through the formation of a corpus, free-floating reading and selection of 382 record units (RU) from the total material. These RUs were condensed by theme into 12 units of meaning and grouped into five categories, namely: The incorporation of Curricular Parameters and the pedagogic strategies used by teachers, which presented a total of $18.32 \%$ of the analyzed material; Feelings and experiences of teachers towards alcohol and alcoholics, $19.88 \%$; Approaches to alcohol by teachers and the pedagogical strategies developed in the classroom, 23.56\%; teachers' conceptions about alcohol $17.81 \%$; Behavior and interaction among students on alcohol from the perspective of teachers $20.43 \%$. The categories are presented as follows.

\section{The incorporation of curricular parameters and the pedagogic strategies used by teachers}

This category was composed of 70 RUs and 3 units of meaning relating to transversal themes and the pedagogic strategies by teachers. In the 1990s, the MEC invested in a new approach, seeking transversality in the school curricula. The National Curriculum Parameters include transversal content and themes united under the name "social life and ethics", which must cover: ethics, cultural diversity, work and consumption, environment, health and sexual orientation. Health, being the right of everyone, should include in its theme student 
understanding in their relationships with the physical and social environment, identifying risk factors and changes in habits necessary for self-care and biopsychosocial well-being(13).

The results point to a lack of knowledge of the curriculum parameters on the part of the teachers. Many interviewees said that they did not know the transversal themes or did not remember them, and even those who said they knew presented discourses that gave only a few examples from the vast list of themes and guidelines to be addressed in the contents, as made explicit in the statement: I know, I've been reading, but at the moment I cannot tell you. I believe that even this [alcohol] is included (E19).

A theoretical construct of the teachers studied was observed, specifically with regard to the conceptualization of strategy. In some situations they overlap this concept with methodology or method, in others they tie-in to the motivational dimension, now widespread in society, as in the statement: To me, they are means you have to better develop your work. They are motivations, they are resources that you use to get students interested in participating in the class, in school activities and to get them to enjoy the class as well (E10).

Attention is drawn to the fact that the Curriculum Guidelines are organized around the strategies, methods and other technologies and the specificities of these actions are not present in the mental mapping of the subjects or in the scrutinization of their actions. Until recently, teacher training was aimed at teaching through transmission of knowledge seeking the effective performance of teachers in the classroom. This concept has been rethought and substituted by an educational practice that the teacher develops, emphasizing the teacher's knowledge and the base of knowledge guided by the understanding of experience ${ }^{(14)}$.

\section{Feelings and experiences of teachers towards alcohol and alcoholics}

This category encompassed 76 RUs and two units of meaning that discuss the experiences and the feelings expressed by teachers. The use of alcoholic beverages causes events within the social groups and has a marked influence on their values and beliefs. To understand alcoholism in its various dimensions, the fact that alcoholism is a disease stigmatized by society must be understood and that this can influence people's attitudes through their opinions, lived experiences, beliefs, values and their own knowledge within the social groups, which are mediated by social interactions.
The feelings are affective states that do not get confused with sensations and that we learn to recognize throughout life such as fear, grief, deception, anger, consternation, tenderness, compassion, wonder and concern for the other. The basic emotions such as fear, for example, are also socially constructed and the feeling is classified according to the rules and standards of a particular culture or society ${ }^{(15)}$.

In relation to the lived experiences of the teachers, family experiences mainly involving the use in gatherings of a social nature; people who describe dangerous situations or violence that occurred with neighbors or friends; and some professionals who portray the events inside educational institutions both with students and with colleagues emphasizing the abuse of alcoholic beverages can be highlighted. To illustrate this situation the following statement is presented: I only had one experience with students. It was in a school I worked for eighteen years, at the end of the year I noticed that the students were a bit strange, they were talking too much, were too happy, laughing, talking loudly. I found that they had bought a bottle of wine and were drinking it hidden in the school parking lot (E09).

In contrast, the confrontation of ideas was seen from participants when asked about their feelings towards alcoholic people. The feelings cited range from anger to compassion. However, pity and fear are the feelings manifested in many of the testimonies, resulting that in the same statement are presented feelings of disgust and compassion, as this statement demonstrates: Disgust. I cannot stand it, I cannot stand drunk people. It's a pity because it's an addiction. You see that the person has difficulty overcoming this, to avoid. Dismay and sadness. Sadness because it is a human weakness (E25).

\section{Approaches to alcohol by the teachers and the teaching strategies developed in the classroom}

This category has 90 RUs and two units of significance regarding the approach of alcohol by the teachers. The reason that youths consume drugs, even in spite of their differences and specificities, is due to the social reality that no longer fulfills their needs. Usually, adults take drugs to remain integrated in society, without concealing their contradictions; but youths do so because they do not accept the inconsistency of society, observing its degradation of values ${ }^{(16)}$.

In this process, teachers play a fundamental role because, supposedly, they are the keepers of scientific knowledge related to substances and their effects on the human organism, in addition to creating a privileged 
channel of communication with the students. However, the teacher's personality and habits directly influence the preventive work by creating a favorable environment within the room, such as providing a positive example and their openness to dialogue.

Discussions regarding alcohol are tackled by teachers through their life experiences with these substances, showing essentially the dangers of alcohol use in adolescents, or by reproaching its use by youths. They also identify the referral of cases of alcohol involvement to the higher authority of the school or a specialized center that can aid in the recovery of the student. This approach is characterized in the statement: I always tell them I'm here to tell you what is healthy, what is good for your organism, what you should do. Now what each will do with your body, I cannot take care of you, I say this to them, we discuss, what is good and what is not (E04).

With respect to strategies for developing content on alcohol, most of the interviewees said they use group dynamics to facilitate discussion in the classroom, reading current texts, dramatization, redaction, videos, and also scheduled classes within the content provided for certain disciplines that add alcohol into the topics of quotidian life. The disciplines that showed the approach to alcohol in the programs of the courses were science and arts, as shown by the statement: In the seventh grade, there is another way, we work with the question of alcohol along with drugs, dependency and the nervous system. When we work with the issue of the nervous system we work with the effects of nicotine, caffeine and alcohol. This is usually what's done (E03).

With this, the school needs to set standards and practices to be followed by the teachers so they can make happen what had been proposed within their area of activity. Preventive measures must be focused "on the field of emotions, feelings and interpersonal relationships, valorizing the self-confidence and selfesteem of the students, [...] the development of skills and attitudes that promote personal aggrandizement and their better integration into the group"(17).

\section{Teachers' concepts regarding alcohol}

This category has 68 RUs and one unit of meaning that addresses the concepts of alcohol. The concepts observed in the discourses of teachers elucidate ideological postures, beliefs and values about alcohol, which show the significance with which this substance is represented in the quotidian of the subjects. The professional practice is permeated by the field of knowledge and subjectivity, reflecting the beliefs, experiences, values and feelings related to the phenomena experienced.

In this sense, there are several proposals and focuses regarding models and theories related to the question of alcohol and other drugs, indicating the great difficulty and complexity that the issue presents. The focus of the dimension of the problem used in this study was based on five models(18): ethical/legal - addressing the law and social security; moral - making the subject responsible for their substance use; medical or disease - drug dependency as a disease; psychosocial - social learning of the components and social and sociocultural interaction - the result of social forces as a function of the cultural environment ${ }^{(18)}$. It is important to highlight that the depositions express significant inhibition of the phenomenon, i.e. a certain trivialization of what is considered social use by the people, hampering the identification of the risks caused by abuse.

It is observable that the concepts of teaching regarding alcohol use are based primarily on the structures of the psychosocial and ethical/legal models, inserted in the social construction of the drug phenomenon, as exemplified by the statement: Alcohol is a beverage, it is a licit drug. It is prohibited for minors under eighteen. I am against people drinking before they are 18 years of age. Now this is what most people see, children actually ingesting alcohol, which is prohibited (E23). The teachers largely recognize the risks in the socio-economic, political and individual spheres that enable the expansion of their views on the subject. Although some statements do not clearly establish a causal relationship, they may indicate that social transformations are the result of globalization that transforms facts, products and quotidian information and brings the youth close to experimentation with drugs and their consequent dependence.

\section{Behavior and interaction among students regarding alcohol use from the view of the teachers}

The final category presents 78 URs and two units of meaning discussing the perception of the teachers regarding student behavior and their interaction in discussions about alcohol. Facing the drug phenomenon, it becomes important to comprehend the role of attitudes in determining behavior. Attitudes have an instigator component of consistent behavior with the cognitions and emotions related to determinant objects. People's experiences influence their current attitudes, through the current situation in which they operate and manifest themselves through behavior(19). 
It is emphasized that the teachers, despite exhibiting their knowledge about changes in the behavior of those who use alcohol, do not seem to visualize the extent of the consequences that such abuse causes in the lives of adolescents, since they assume a posture to minimize the responsibility of the school, both facing the phenomenon or facing coping with it, as in this statement: I try to pretend that I do not realize. I treat it in the most natural way possible, answer the questions that they ask me, I try to act naturally, so they do not excite themselves, to solve their problems and not bother me, I do not do anything strange (E26).

The discourses indicate a change of behavior of students who make use of any psychoactive substance, however, the professionals cannot manage to make the specific identification of alcohol associated with these modifications. In contrast, the interaction of the students in the discussion of alcohol appears to be facilitated and mediated by the teachers who are available to address these quotidian issues of the students, and believe that every discussion is permeated with help and mutual cooperation, as demonstrated by the statement: I think they exchange experiences, they seem to pass information. I see no criticism, I see it more as cooperation. In many aspects they are cooperative. I see certain complicity, they understand.

I never saw aggression or criticism or mockery or anything, they know how to listen to the other (E07).

The consumption of alcohol by groups of youths is facilitated or repressed within the same group that they are inserted. The need for identification with the group facilitates the initial involvement with experimentation and later with the habit of drinking at celebrations. Thus, the school must be prepared to confront the power of alcohol and other drugs and minimize the consequences within the school environment(20).

\section{Conclusion}

It was concluded that, according to the representations of the teachers, the focus of the principal public policies regarding the use or abuse of alcohol is directed towards adolescents, while the teacher is presented with the urgent need to address the issue in their day-to-day work, regardless of their knowledge, their beliefs and their attitudes. This framework creates a tense quotidian in which health education opportunities are lost as a result of difficulties in comprehending a subject that is situated on unsafe ground due to its location between the stimulated and the denied.

It is observed, in this sense, how alcohol, for the teachers, fluctuates between the socially accepted and the negative in essence, this fluctuation has its roots in the experiences of these individuals, especially in the personal dimension of the lived. In this article, it becomes important to comprehend how these experiences ultimately determine the attitudes and values expressed faced with this object, while experiences and beliefs have mutual influence among themselves and in the determination of individual and social practices.

The inclusion of content regarding alcohol and other drugs should consider the social permission of its use as a generator of pleasure and the repercussions of the inappropriate use of these substances in the lives of the students. Thus, seeking harm reduction in the consumption of alcohol and other drugs as a possible alternative, reaches mainly the most vulnerable populations such as children and adolescents. It should also encourage public discussion about alcoholic beverages, especially in the school environment, involving youths, their families, the technical-pedagogical staff and the community. However, moral panic, the demand for repressive measures and the call for the public security police should be avoided to ward off the possible risks in the contact of adolescents with drugs.

Therefore, we suggest the participation of nurses as health educators in this process of transforming the school, with techno-scientific and legal apparatus to develop programs at all three care levels and in all operating areas of the National Health System, especially the services of primary care aimed at health promotion. The process of risk prevention for the use of alcohol and other drugs has proved more effective when there is the inclusion of this professional in educational and preventative programs in the school space and especially when this inclusion generates a process of knowledge alliance between these two professionals, so that new knowledge, adaptable to the reality that responds to these current challenges, is constructed.

\section{References}

1. Lopes GT, Bernardes MMR, Felipe ICV, Acauan LV, Casanova EG, Lemos BKJ. O enfermeiro no ensino fundamental: desafios na prevenção ao consumo de álcool. Esc Anna Nery Rev Enferm. 2007; 11(4): 712-6.
2. García de Jesús MC, Ferriani MGC. School as a "protective factor" against drugs: perceptions of adolescents and teachers. Rev. Latino-Am. Enfermagem. 2008; 16(spe):590-4. 
3. Martini JG, Furegato ARF. Teachers' social representations on drug use in a secondary school. Rev. Latino-Am. Enfermagem. 2008; 16(spe):601-6.

4. Wright MGM, Gliksman L, Khenti A, Furegato ARF. Research on the drugs phenomenon from the perspective of multicenter studies in Latin America and the Caribbean. Rev. Latino-Am. Enfermagem. 2009; 17(spe):759-61.

5. Rokeach M. Crenças, atitudes e valores: uma teoria de organização e mudança. Rio de Janeiro: Interciência; 1981.

6. Berger PL, Luckmann T. A construção social da realidade: tratado de sociologia do conhecimento. $13^{a}$ ed. Petrópolis: Vozes; 1996.

7. Amâncio L. Identidade social e relações intergrupais. In: Vala

J, Monteiro MB, organizadores. Psicologia Social. 6a ed. Lisboa: Fundação Calouste Gulbenkian; 2004. p. 387-410.

8. Meloni JN, Laranjeira R. Custo social e de saúde do consumo do álcool. Rev Bras Psiquiatr. 2004; 26(supl 1): 7-10.

9. Galduróz JC, Noto AR, Fonseca MA, Carlini EA. V Levantamento Nacional sobre o Consumo de Drogas Psicotrópicas entre Estudantes do Ensino Fundamental e Médio da Rede Pública de Ensino nas 27 Capitais Brasileiras - 2004. Brasília: Centro Brasileiro de Informações sobre Drogas Psicotrópicas - CEBRID: Escola Paulista de Medicina; 2004.
10. Secretaria de Educação Fundamental (BR). Parâmetros Curriculares Nacionais: introdução aos parâmetros curriculares nacionais. Brasília (DF): MEC; 1998.

11. Minayo MCS. Pesquisa social: teoria, método e criatividade. 22aed. Petrópolis: Vozes; 2003.

12. Bardin L. Análise de conteúdo. Lisboa: Edições 70; 2004.

13. Secretaria de Educação Fundamental (BR). Parâmetros Curriculares Nacionais: introdução aos parâmetros curriculares nacionais, Volume 1. Brasília: MEC/SEF; 1998.

14. Nunes CMF. Saberes docentes e formação de professores: um breve panorama da pesquisa brasileira. Educ Soc. 2001; 22(74): 27-42.

15. Costa JF. Sem fraude nem favor: estudos sobre o amor romântico. Rio de Janeiro: Rocco; 1998.

16. Bucher $\mathrm{R}$, organizador. As drogas e a vida: uma abordagem biopsicossocial - CORDATO. São Paulo: EPU; 1988.

17. Hühne LM, Braga M. Drogas: educação, prevenção e práticas criativas. Rio de Janeiro: UAPÊ; 2004.

18. Pillon SC, Luis MAV. Modelos explicativos para o uso de álcool e drogas e a prática da enfermagem. Rev. Latino-Am. Enfermagem. julho-agosto 2004; 12(4): 676-82.

19. Rodrigues A, Assmar EML, Jablonski B. Psicologia Social. $18^{a}$ ed. Rio de Janeiro: Vozes; 2000.

20. Abramovay M. Drogas nas escolas: versão resumida. Brasília: UNESCO; 2005. 